\title{
Validation of Rainfall Reanalysis Data to Explore Changes in Oldeman Agricultural Climate Patterns Due to Variability of Surface Temperature Anomalies with Time Series Analysis Techniques (Case Study of Dumai City for 30 Years Period)
}

\author{
Bagus Primohadi Syahputra $^{1^{*}}$, Dedi Sucahyono \\ ${ }^{1,2}$ School of Meteorology Climatology \& Geophysics, Perhubungan 1 Street, No. 5, Meteorological Housing of \\ BMKG, Pondok Betung, Bintaro-Tangerang Selatan, Banten, Indonesia, 15221 \\ *Corresponding Author: Bagus Primohadi Syahputra, bagus.primohadi38@gmail.com
}

\begin{abstract}
Indonesia is a country with a population that still uses the agricultural sector as the highest livelihood. The Central Statistics Agency said 38.61\% were in this sector. However, the issue of climate change caused by an increase in global temperature has begun to impact the agricultural sector in several regions. Therefore, this study aims to understand the effect of increasing surface temperature anomaly on the Oldeman climate pattern in Dumai City. The data used are in-situ observation rainfall data for 1981 - 2010, rainfall reanalysis data for 1991 - 2020, surface temperature anomaly data for 1991 - 2020. The data validation methods used are spearman correlation and Kendall-tau methods. The approach to explore changes in the Oldeman climate pattern uses time series analysis techniques such as $A C F, P A C F$, and moving average of 1 year lag-time with a period of 10 years. The rainfall data validation test result show that the average spatial correlation value is 0.86 . It can be used to explore time-series climate data in 3 locations in Dumai. As a result, time series analysis found a positive trend in rainfall data significantly along with the temperature anomaly but the Oldeman's climate pattern analysis in Dumai is monitored as stable in type B1. Overall, it is concluded that the change in the surface temperature anomaly variability and trend as a manifestation of climate change in Dumai has not impacted in the Oldeman agricultural climate patterns.
\end{abstract}

Keywords: Climate Change, Oldeman, Time Series, Rainfall, Temperature

\section{Introduction}

Indonesia is one of the countries that is located in a surplus area of heat energy for all seasons which has an impact on the distribution of monthly rainfall which is quite high in the territory of Indonesia. (Tjasyono, 2012). This certainly has an impact on all sectors of human life that affect the economic, social, cultural, political, security situation, one of which is also the agricultural sector. The failure of crop production has a further impact on the national food availability which will worse affect social and economic stability (Ariffin, 2019). The Central Statistics Agency (BPS) through its official website issued a press release as of 2018, the highest percentage of Indonesian people's livelihoods reaching $38.61 \%$ were in the agricultural sector. This really needs to be watched out for considering the large number of people who need good management of agricultural production by understanding the regional climate patterns of each region.

Dumai is one of the cities in the Riau province with the second largest area in Indonesia with a total area of $1.727 .385 \mathrm{~km}^{2}$ (Budhiman, 2021). Through the official website of the Central Statistics Agency, Dumai City provides information on agricultural conditions in Dumai, which has the highest productivity for rubber, oil palm, coconut, cocoa and sweet potatoes and is one of the contributors to the highest agricultural 
productivity in Riau Province. This potential needs to be monitored in the agricultural management process, one of which is understanding regional climate patterns that will be useful for managing agricultural production. The most suitable agricultural agro-climatic pattern in Indonesia is the Oldeman climate type which uses monthly rainfall data (Fadholi $\&$ Supriatin, 2016). However, to monitor and analyze the mapping of the oldeman agricultural climate pattern using rainfall data from the BMKG rain monitoring post, it has drawbacks, namely in terms of minimal quantities so that it cannot produce an optimal oldeman agroclimate map. (Paski \& Sepriando, 2017). So Paski and Sepriando mapped the agroclimate pattern of Oldeman agriculture using satellite rainfall estimation data.

The limited number of rain posts becomes more risky with the issue of climate change which has had an impact in several regions such as China and India. Climate change in agriculture has an indirect impact on the country's economy (Mendelsohn, 2014). The direct impact of climate change on agriculture causes losses in the form of crop failure or failure to plant seeds due to unstable weather conditions (Yuliana, 2020). Climate change events can be marked by an anomaly surface temperature element which is an indicator of global warming caused by carbon gas emissions. $\mathrm{CO}^{2}$ gas is produced by anthropological activities and gives the effect of greenhouse gases that become more radiation absorbers (Matawal \& Maton, 2013).

So, this study aims to understand and explore the impact of climate change through the variability and trend data of the surface temperature anomaly on the rainfall value of the reanalysis model to cover the lack of rain post observation data through the validation stage so that the rainfall reanalysis model data can be used in the analysis of oldeman agroclimatic patterns. in Dumai City.

\section{Method}

2.1. Data \& Location

In this study, monthly climate rainfall data is used as the main research object with the type of in-situ observation as a parameter in the Oldeman climate analysis. The data is sourced from the meteorological observation post for rainfall from the Meteorology, Climatology \& Geophysics Agency of Riau Province which has a period from 1981 to 2010. Then, the rainfall reanalysis model data is downloaded via the https://cds.climate.copernicus.eu/ page with spatial resolution $0.25^{0} \times 0.25^{0}$ grid data and monthly average temporal resolution for the period $1990-2019$. Next is the surface temperature anomaly data as secondary data which is downloaded via the https://www.ncdc.noaa.gov page for 3 observation locations with a time period of 1991 - 2020. The location used in this study is located in Dumai City, Riau Province by using 3 coordinate location points that are representative for the region. The coordinates are $20 \mathrm{U} 101.25 \mathrm{E}, 1.75 \mathrm{U} 101.25 \mathrm{E}$ and $1.5 \mathrm{U}$ 101.5E.

\subsection{Data Processing Flow}

The research was conducted by collecting meteorological postal rainfall data available in tabular format (.xlsx) which had gone through the preprocessing stage. The next step is to download the rainfall reanalysis model data in binary format netcdf (.nc) which will then be converted into text data (.txt) through the Panoply Data Viewer software from NASA. The rainfall reanalysis model data is then processed through the preprocessing stage through Microsoft Office Excel software to produce information that is ready for visualization and analysis. Before conducting a data validation test for the rainfall analysis model, a normality test was carried out using Minitab19 software on both data to facilitate the selection of the analytical method to be used. Next is to test the validation of the suitability of the rainfall reanalysis data using python 
programming with the method used according to the data type of the normality test results. The validated rainfall data is then processed to produce an analysis of the time series characteristics and the pattern of the oldeman agricultural climate type by considering the surface temperature anomaly data descriptively using Microsoft Office Excel.

\subsection{Analysis Methods}

To produce an output in the form of determining and identifying the Oldeman climate pattern as the surface temperature anomaly increases, several analytical methods are carried out as follows:

A. Normality Test

Normality test is a test carried out to determine the level of fairness in the form of data distribution within the range of the average value. This test will determine the type of data based on the level of normality where parametric data is normal distribution data and nonparametric data types are abnormal distribution data (Oktaviani, 2014). The testing method used in this research is the Kolmogorov Smirnov method.

B. Spearman Rank Correlation Validity Test

Spearman correlation used to test the significance of associative sorrelation in nonparametric data (Suharto, 2016). The formula is as shown below (Sugiyono, 2019):

$$
r_{S}=1-\frac{6 \sum_{i=1}^{N} d_{i}^{2}}{N^{3}-N}
$$

The interpretation of the Spearman rank correlation value uses the classification from Dancey, et al as shown in the following table (Reidy, 2004) :

Tabel 1. Interpretation of Spearman Rank Correlation

\begin{tabular}{|c|c|}
\hline Spearman $r$ & Correlation \\
\hline$>0.70$ & Very strong relationship \\
\hline $0.40-0.69$ & Strong relationship \\
\hline $0.30-0.39$ & Moderate relationship \\
\hline $0.20-0.29$ & Weak relationship \\
\hline $0.01-0.19$ & No or negligible relationship \\
\hline
\end{tabular}

C. Kendall Tau Correlation Validity Test

Kendall-tau test is a nonparametric bivariate distribution test that is used to determine the level of significance of the relationship between variables in the same data population. (Newson, 2002). The kendall-tau correlation equation is as follows:

$$
\tau X Y=E\left[\operatorname{sign}\left(X_{1}-X_{2}\right) \operatorname{sign}\left(Y_{1}-Y_{2}\right)\right],
$$

The interpretation of the Kendall-tau correlation value uses the classification of Kendall and Gibbons in 1990 as follows (Gibbons, 1990):

Tabel 2. Interpretation of Kendall-Tau Correlation

\begin{tabular}{|c|c|}
\hline Kendall-Tau $(\mathrm{p})$ & Correlation \\
\hline$>0.30$ & Strong \\
\hline $0.20-0.29$ & Moderate \\
\hline $0.10-0.19$ & Weak \\
\hline$<0.10$ & Very weak \\
\hline
\end{tabular}


D. Autocorrelation Test

This test aims to determine whether in a time series there is a correlation between residual data in period $t$ with residues in the next period $t+1$ (Nugroho, 2016). The equation in this test is as follows:

$$
s_{k}=\frac{1}{n} \sum_{i=1}^{n-k}\left(y_{i}-\bar{y}\right)\left(y_{i+k}-\bar{y}\right)=\frac{1}{n} \sum_{i=k+1}^{n}\left(y_{i}-\bar{y}\right)\left(y_{i-k}-\bar{y}\right)
$$

E. Partial Autocorrelation Test

The Partial Autocorrelation Function is the correlation between $\mathrm{Zt}$ and $\mathrm{Zt}+\mathrm{k}$ after the influence of the confounding variable $\mathrm{Zt}-1, \mathrm{Zt}-2, \ldots, \mathrm{Zt}-\mathrm{k}+1$ is removed. Partial autocorrelation coefficients are usually denoted by phi kk (Tinungki, 2019). The equation of the partial autocorrelation test is as follows:

$$
\phi_{i k}=\operatorname{Corr}\left(Z_{t}, Z_{t-k} \mid Z_{t-1}, Z_{t-2}, \ldots, Z_{t-k+1}\right)
$$

F. Moving Average Test

This test is carried out by taking samples from the data population with a certain average time period interval (Rachman, 2018). The equations used in this method are as follows:

$$
M A=\frac{A_{1}+A_{2}+\ldots+A_{n}}{n}
$$

G. Oldeman Climate Analytics

The Oldeman climate pattern is a climate zone grouping scheme based on the amount of water needed by plants, especially rice and secondary crops with reference to the number of wet and dry months in a one year period. (Nasution \& Nuh, 2019). Determination of the type of wetness condition of rainfall is divided into 3 values of the range of rainfall each month during the climate analysis period of at least 10 years (Livezey et al., 2007). Wet months if the average rainfall is more than $200 \mathrm{~mm} / \mathrm{month}$, dry months if the rainfall is below $100 \mathrm{~mm} / \mathrm{month}$ and humid months are between $100-200 \mathrm{~mm} /$ month. So Oldeman has climate zones, namely zone $\mathrm{A}$, zone $\mathrm{B}$, zone $\mathrm{C}$, zone $\mathrm{D}$, and zone $\mathrm{E}$ with sub zones from 1 to 5 . Through this division, it is hoped that this division can be a guide for farmers in making policies in irrigation management.

Table 3. Oldeman climate type

\begin{tabular}{|l|l|l|l|l|l|l|l|l|l|l|l|l|l|l|l|l|l|}
\hline Type & A1 & A2 & B1 & B2 & B3 & C1 & C2 & C3 & C4 & D1 & D2 & D3 & D4 & E1 & E2 & E3 & E4 \\
\hline Wet & $>9$ & $>9$ & $7-9$ & $7-9$ & $7-9$ & $5-6$ & $5-6$ & $5-6$ & $5-6$ & $3-4$ & $3-4$ & $3-4$ & $3-4$ & $<3$ & $<3$ & $<3$ & $<3$ \\
\hline Arid & $<2$ & $2-4$ & $<2$ & $2-4$ & 4 & $<2$ & $2-4$ & $5-6$ & 6 & $<2$ & $2-4$ & $5-6$ & 6 & $<2$ & $2-4$ & $5-6$ & $>6$ \\
\hline
\end{tabular}

\section{Results and Discussions}

A. Normalitaty Test

The use of rainfall reanalysis model data as a transition to minimal observational primary data for climate modeling requires a normality test and the results are shown in Figure 1. It can be seen that both the observation data (obs acronym) and model data in 4 conditions with the acronym mod1 are rainfall at coordinates $2 \mathrm{U} \cdot 101.25 \mathrm{E}, \bmod 2$ acronym for rainfall at coordinates $1.75 \mathrm{U} 101.25 \mathrm{E}, \bmod 3$ acronym for rainfall at coordinates $1.5 \mathrm{U} 101.5 \mathrm{E}$ and acronym modtotal for spatial average rainfall in the city of Dumai from the 3 locations show an abnormal distribution shown by The P significance value is more than 0.05 where the observation rainfall data has a $P$ value of 0.289 , the 
model rainfall data at the first location has a $\mathrm{P}$ value of 0.274 , the model rainfall data at the second location has a $\mathrm{P}$ value of 0.472 , the model rainfall data at the third location has a $\mathrm{P}$ value. 0.84 and the regional average model rainfall data has a $\mathrm{P}$ value of 0.5 . Thus, the correlation validation test uses a nonparametric test scheme.

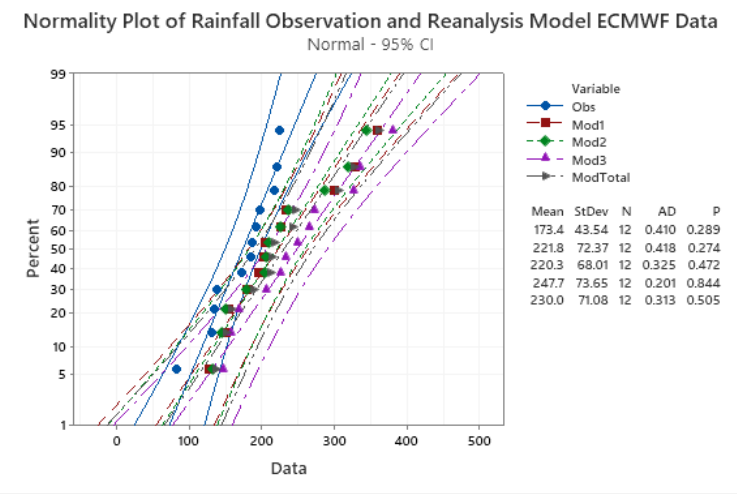

Figure 1. Normality result

B. Spearman \& Kendall-Tau . Rank Correlation Validation Results

The results of the normality test show that the data is of a non-parametric type, so the correlation uses the Spearman and Kendall-tau correlation types with the results in Figure 2. Through the first correlation test method, namely the Spearman correlation test, it is shown that the observation data has an $r$ value that varies with the model data of 0.82 on the data. Reanalysis at location 2 (the acronym Mod2) to 0.86 on the regional average reanalysis data in Dumai. This indicates that through the Spearman rank correlation test, the monthly reanalysis model of rainfall climate data for 30 years in Dumai has a very strong relationship referring to the Spearman correlation classification in table 1.
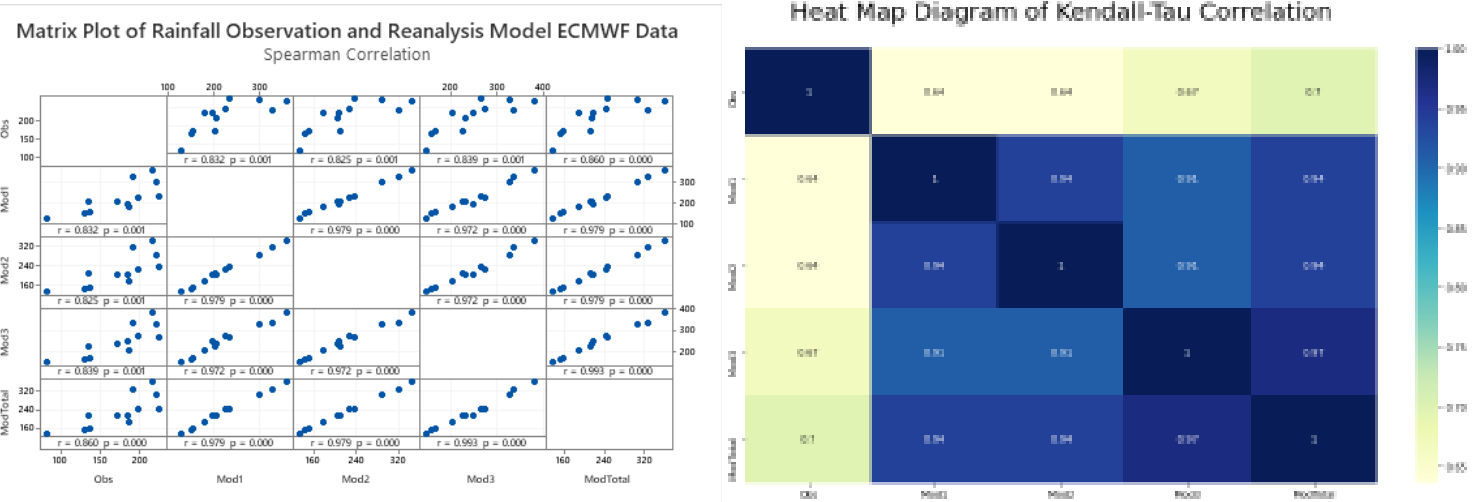

Figure 2. Spearman correlation matrix plot (left) \& Kendall-Tau correlation heat map (right)

Then, through the Kendall-tau test method, it is shown in Figure 2 if the observation data has $p$ value 0.64 to the data in the rainfall model at location 1 and location 2 , the $p$ value of kendall-tau 0.67 is found in the relationship between rainfall observation data and rainfall model data at location 3 and the highest $p$ value is 0.7 to the average rainfall data. spatial area in Dumai. Thus, based on table 1, the relationship between the observed rainfall climate data has a strong relationship with the rainfall climate data reanalyzed by the ECMWF model. Overall, the reanalyzed rainfall model data can be used in determining and exploring changes in Oldeman climate patterns in Dumai to replace observational data because they have a strong relationship. 


\section{Autocorrelation and Partial Autocorrelation Test Results}

Through the Lag-time scheme, then proceed to see the correlation between time periods to detect seasonal values in lag data that can affect the value of the moving average trend. Figure 4 shows the values and autocorrelation diagrams for 4 conditions, namely data at the first location, second location, third location and data on the spatial average of the area. The results of autocorrelation at the first location with a lag value of up to 21 showed no significant value was shown because the data were still within the normal limit interval for autocorrelation as well as for location 3. However, at the second location there was a significant value even though there was no repetition. This is quite influential on the average ACF value of the region although it still does not show a seasonal effect. The same thing also happened to the results of the partial autocorrelation test. This indicates that trend testing through the moving average method has no significant effect and identification of changes in the average value of the 10-year rainfall climate free from seasonal influences.
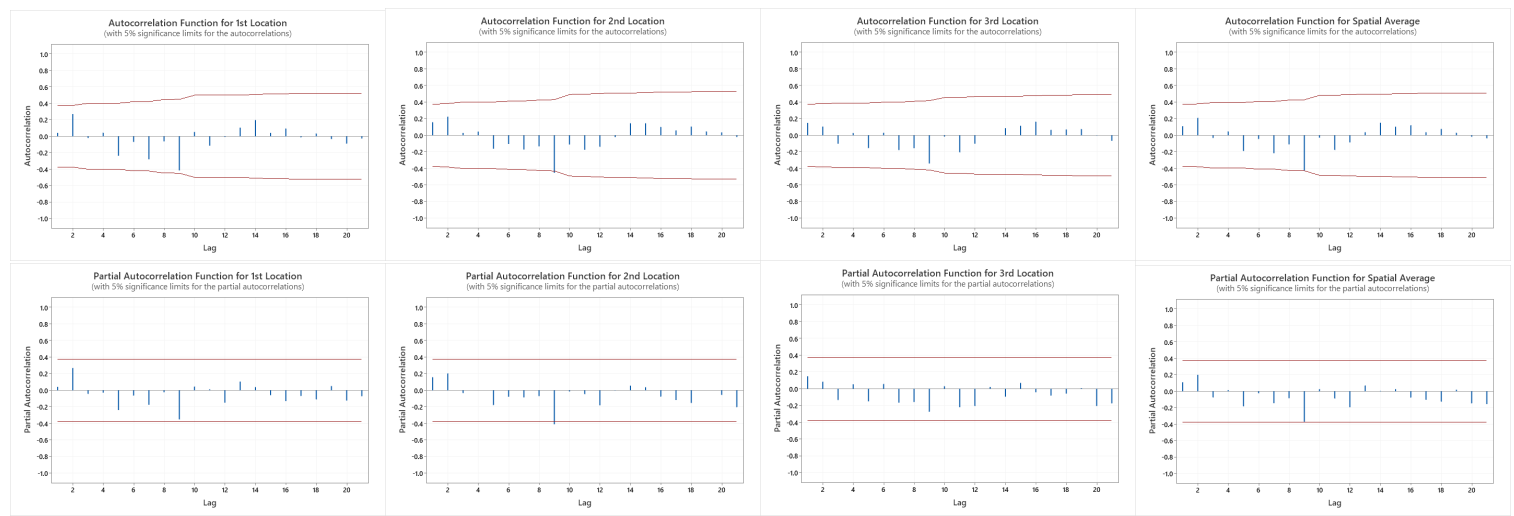

Figure 3. Autocorrelation (up) \& partial autocorrelation (bottom) for 4 conditions

D. Oldeman Climate Change Exploration

Rainfall reanalysis data measured by the lag-time scheme with each lag period is an average of 10 years of normal climate measurements at each coordinate location point and spatially the regional average then analyzed to explore rainfall conditions and changes in the pattern of the Oldeman zone. Shown in Figure 5, the left is a graph of the amount of annual rainfall for the 10-year climate period as measured by a 1-year lag movement, a pattern of decline is found in the 7th lag or the 1997-2006 period with the lowest value of $2571 \mathrm{~mm} /$ year and then increases again until it is recorded The highest rainfall is $2958 \mathrm{~mm} /$ year at lag 17 . Through the trend approach, it can be seen that the average rainfall data for the 10 -year climate measurement has increased along with the increasing trend of the surface temperature anomaly data in the city of Dumai as seen in Figure 4 on the left. The surface temperature anomaly in Dumai varies with an increasing trend of temperature anomalies occurring from $-0.150 \mathrm{C}$ to $0.50 \mathrm{C}$ during the last 30 years in Dumai City. The effect of the surface temperature anomaly on rainfall ranges from $12.1 \%$ through regression analysis as shown in Figure 4 on the right. Although the relationship between rainfall data and annual surface temperature anomalies has a negative gradient, through a 10 -year climate measurement scheme, the two trends have a positive gradient that increases with each other. 

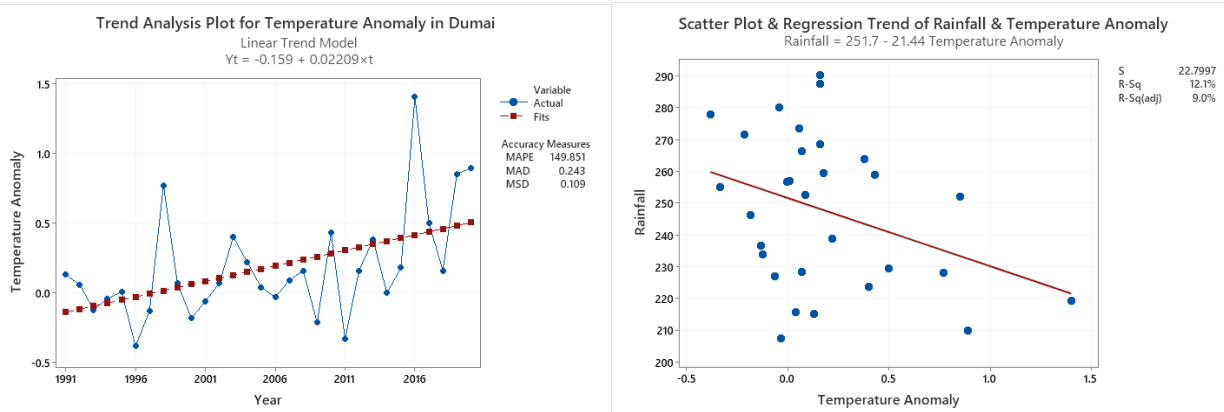

Figure 4. Trend of Temperature Anomaly (left) \& the Regression to the Rainfall (right)

The trend of increasing rainfall through the 10-year moving average turned out to have a significant visual correlation with the distribution pattern of wet, dry and humid months in the determination of the Oldeman climate zone. Figure 5 on the right shows an increasing trend of wet months (WM) and a downward trend in the accumulation of moist months (MM) so that the pattern of the Oldeman climate zone is summarized in table 4 where in general the Dumai climate zone is still around B1. Although there is a $\mathrm{C} 1$ zone on average and a D1 zone in the first location.
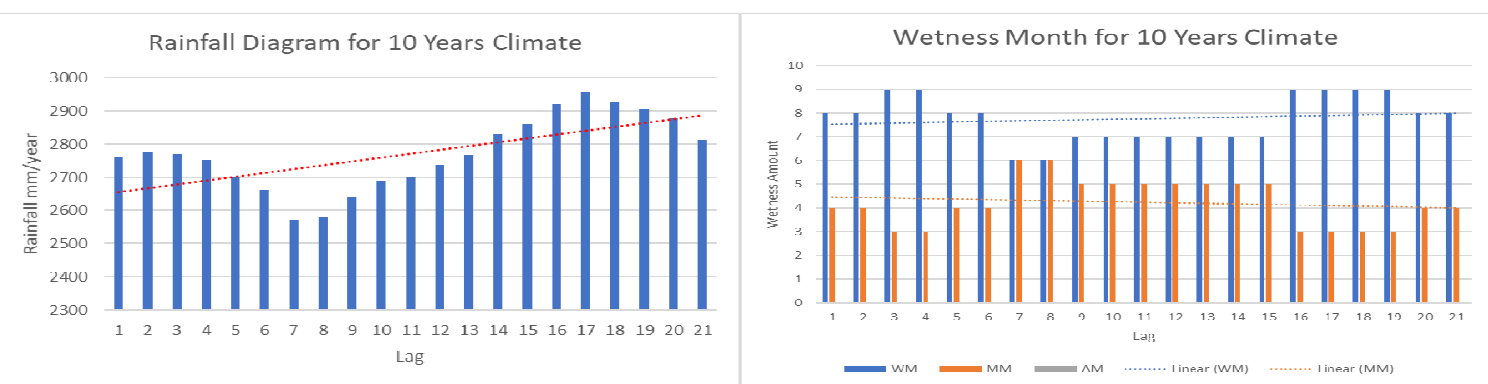

Figure 5. Rainfall Accumulation for 10 year moving average (left) \& It's Wetness Condition (right)

Table 4. Oldeman zone by moving average of 10 years climate scheme

\begin{tabular}{|c|c|c|c|c|c|c|c|c|c|c|c|c|c|c|c|c|c|c|c|c|c|}
\hline \multirow[b]{2}{*}{ Condition } & \multicolumn{21}{|c|}{ Lag } \\
\hline & 1 & 2 & 3 & 4 & 5 & 6 & 57 & 8 & 9 & 10 & 11 & 12 & 13 & 14 & 15 & 16 & 17 & 18 & 19 & 20 & 21 \\
\hline Loc1 & C1 & B1 & B1 & B1 & C1 & C1 & C1 & D1 & C1 & C1 & C1 & B1 & B1 & B1 & B1 & B1 & B1 & B1 & B1 & B1 & B1 \\
\hline Loc2 & B1 & B1 & B1 & B1 & B1 & B1 & C1 & C1 & C1 & B1 & B1 & B1 & B1 & B1 & B1 & B1 & B1 & B1 & B1 & B1 & B1 \\
\hline Loc3 & B1 & B1 & B1 & B1 & B1 & B1 & B1 & B1 & B1 & B1 & B1 & B1 & B1 & B1 & B1 & B1 & B1 & B1 & B1 & B1 & B1 \\
\hline Spatial & B1 & B1 & B1 & B1 & B1 & B1 & C1 & C1 & B1 & B1 & B1 & B1 & B1 & B1 & B1 & B1 & B1 & B1 & B1 & B1 & B1 \\
\hline
\end{tabular}

\section{Conclusions}

The use of reanalyzed model data that has been validated gives correlation results that have a very strong relationship with observational rainfall data. The data also does not have a significant seasonal pattern, so that the data can be used in the analysis of the oldeman agricultural climate pattern which gives results if the oldeman climate pattern is stable in zone B1 in Dumai until the last time period 2020. Although there is a significant increase in the trend of the 10-year cumulative rainfall value which is influenced by the increase in surface temperature anomalies as a manifestation of climate change in Dumai, but this has not yet affected the Oldeman climate system in Dumai. 


\section{References}

Ariffin. (2019). Metode Klasifikasi Iklim di Indonesia. UB Press.

Budhiman, I. (2021, March 8). 9 Kota Besar di Indonesia Menurut Luas Wilayah. Ternyata Bukan Jakarta! 99 Berita Properti. https://www.99.co/blog/indonesia/daftar-kotabesar-di-indonesia/

Fadholi, A., \& Supriatin, D. (2016). Sistem pola tanam di wilayah priangan berdasakan klasifikasi iklim oldeman. Jurnal Geografi Gea, 12(2). https://doi.org/10.17509/gea.v12i2.1788

Gibbons, K. M. G. (1990). Rank Correlation Methods (5th ed.). Griffin.

Livezey, R. E., Vinnikov, K. Y., Timofeyeva, M. M., Tinker, R., \& van den Dool, H. M. (2007). Estimation and Extrapolation of Climate Normals and Climatic Trends. Journal of Applied Meteorology and Climatology, 46(11), 1759-1776. https://doi.org/10.1175/2007JAMC1666.1

Matawal, P. D., \& Maton, D. (2013). Climate Change and Global Warming: Signs, Impact and Solutions. International Journal of Environmental Science and Development, 4, 62-66. https://doi.org/10.7763/IJESD.2013.V4.305

Mendelsohn, R. (2014). The Impact of Climate Change on Agriculture in Asia. Journal of Integrative Agriculture, 13(4), 660-665. https://doi.org/10.1016/S20953119(13)60701-7

Nasution, M. I., \& Nuh, M. (2019). Kajian Iklim Berdasarkan Klasifikasi Oldeman Di Kabupaten Langkat. JISTech (Journal of Islamic Science and Technology), 3(2), Article 2. https://doi.org/10.30829/jistech.v3i2.3157

Newson, R. (2002). Parameters behind "Nonparametric" Statistics: Kendall's tau, Somers' D and Median Differences. Stata Journal, 2, 45-64. https://doi.org/10.1177/1536867X0200200103

Nugroho, R. E. (2016). Analisis Faktor - Faktor Yang Mempengaruhi Pengangguran Di Indonesia Periode 1998 - 2014. Penelitian dan Aplikasi Sistem dan Teknik Industri, 10(2), 182887.

Oktaviani, M. A. (2014). Perbandingan Tingkat Konsistensi Normalitas Distribusi Metode Kolmogorov-Smirnov, Lilliefors, Shapiro-Wilk, dan Skewness-Kurtosis. Jurnal Biometrika dan Kependudukan, 3(2), 9. http://journal.unair.ac.id/downloadfullpapers-biometrikd8bc041810full.pdf

Paski, J. A. I., \& Sepriando, A. (2017). Pemetaan Agroklimat Klasifikasi Oldeman di Provinsi Bengkulu Menggunakan Data Observasi Permukaan dan Multi Satelit (TMPA dan IMERG). 8.

Rachman, R. (2018). Penerapan Metode Moving Average Dan Exponential Smoothing Pada Peramalan Produksi Industri Garment. Jurnal Informatika, 5(2), 211-220. https://doi.org/10.31294/ji.v5i2.3309

Reidy J, D. C. (2004). Statistics without maths for psychology: Using SPSS for windows. Prentice-Hall.

Sugiyono. (2019). Metode Penelitian Kuantitatif. Alfabeta.

Suharto, S. (2016). Hubungan Daya Tanggap Terhadap Loyalitas Pelanggan (Studi Kasus Pada Nasabah Tabungan Supa PT. BPR Sumber Pangasean Bandar Jaya). Akuisisi: Jurnal Akuntansi, 12(1). https://doi.org/10.24127/akuisisi.v12i1.91

Tinungki, G. M. (2019). The analysis of partial autocorrelation function in predicting maximum wind speed. IOP Conference Series: Earth and Environmental Science, 235, 012097. https://doi.org/10.1088/1755-1315/235/1/012097

Tjasyono, B. (2012). Meteorologi Indonesia (Vol. 1). BMKG.

Yuliana, A. Z. (2020). Analisis Zona Agroklimat Klasifikasi Iklim Oldeman di Kabupaten Sukoharjo. 15. 